\title{
EMISSIONS ANALYSIS ON DIESEL ENGINE FUELED WITH PALM OIL BIODIESEL AND PENTANOL BLENDS
}

\author{
SANTHANAKRISHNAN RADHAKRISHNAN*; YUVARAJAN DEVARAJAN**; ARULPRAKASAJOTHI \\ MAHALINGAM $^{\star *}$ and BEEMKUMAR NAGAPPAN ${ }^{\ddagger}$
}

\begin{abstract}
This study examined the effects of pentanol, palm oil biodiesel blends of varying proportions on the emissions pattern in a constant speed diesel engine. The main intention of this study was to investigate the reductions in $\mathrm{HC}, \mathrm{CO}, \mathrm{NO}_{\mathrm{X}}$ and smoke emissions when deploying four different fuels. The conversion of palm oil into biodiesel was achieved using the base catalysed transesterification process. The four different fuels evaluated were neat palm oil biodiesel (POBD100), pentanol blended with palm oil biodiesel by $10 \%$ volume (POBD90P10), palm oil biodiesel blended with pentanol (POBD80P20) by 20\% volume and petroleum diesel. The experimental work concluded that by fuelling the diesel engine with palm oil biodiesel and pentanol blends, combustions were smooth. It was observed that the pentanol to palm oil biodiesel blend gave respective reduction of $9.3 \%, 3.8 \%, 6.6 \%$ and $2.7 \%$ in $\mathrm{CO}, \mathrm{HC}, \mathrm{NO}_{\mathrm{X}}$ and smoke emissions when compared to neat palm oil biodiesel.
\end{abstract}

Keywords: pentanol, palm oil, biodiesel, emissions.

Date received: 3 February 2017; Sent for revision: 27 April 2017; Received in final form: 7 June 2017; Accepted: 5 July 2017.

\section{ITRODUCTION}

Escalating environmental issues coupled with depletion in petroleum resources have paved the way for global efforts to search for eco-friendly fuels (Amirnordin et al., 2013). Automobiles are widely acknowledged as the major source of greenhouse gas emissions. Diesel engines play a significant role in the power and automobile sectors of industry largely because of its durability and economy. However, diesel engines emit higher emissions when fueled with diesel.

Department of Mechanical Engineering

SRM University, Kattankulathur, Chennai, Tamilnadu, India

** Department of Mechanical Engineering,

Vel Tech Dr R R \& Dr S R University,

Chennai, Tamilnadu, India.

E-mail: dyuvarajan2@gmail.com

* Department of Mechanical Engineering,

Sathyabama University, Chennai, Tamilnadu, India.
A lower emission alternative is needed to lessen the demerits of fossil fuel(Harmiwati and Rahmad, 2015). Biodiesel is made up of long chain alkyl esters produced by reacting lipids with alcohols (Lam et al., 2011). Biodiesel can be deployed in diesel engines without any modification. It can also be blended with petroleum diesel. In spite of its many advantages, the major drawbacks of biodiesel concern higher $\mathrm{NO}_{\mathrm{x}}$ emissions, viscosity and density and lower calorific value (Jaat et al., 2014).

Many studies have proven that by appending higher alcohols to biodiesel much of the drawbacks are reduced (Karabektas et al., 2009; Murcak et al., 2013; Wang et al., 2015). Higher alcohols such as butanol, hexanol and pentanol are incorporated in biodiesel as an oxygenated additive (Rakopoulos et al., 2010). Blending, fumigation, emulsion and dual fuel injection are the existing techniques to append alcohols to fuel. Alcohols can be blended to liquid fuel in the range of $10 \%-30 \%$ by volume. Many 
studies have reported that the addition of alcohol to fuel improves the air and fuel mixing rate during combustion. It also reduces the kinematic viscosity of the fuel (Karabektas et al., 2009; Murcak et al., 2013; Wang et al., 2015). Rakopoulos et al. (2014) investigated the effect of butanol in diesel fuels. They found reductions in $\mathrm{NO}_{x}$ and smoke emissions when fuelled with butanol and diesel blends. This has been attributed to the increase in the oxygen content of the resultant fuel. Campos-Fernandez et al. (2015) examined the effect of appending pentanol to diesel in diesel engines. They reported that by appending pentanol, $2.1 \%$ and $3.5 \%$ reduction in $\mathrm{HC}$ and $\mathrm{NO}_{\mathrm{x}}$ emissions were achieved respectively. Atmanli et al. (2016) examined the effect of blending pentanol to diesel by $10 \%$ and $20 \%$ on volume basis and found $7.8 \%$ reduction in $\mathrm{NO}_{\mathrm{x}}$ emissions by appending $20 \%$ of pentanol to diesel. Additionally, smoke emissions dropped by $8 \%$. Yuvarajan et al. (2017) investigated the effects of adding pentanol to cashew nut shell biodiesel in $1300 \mathrm{rpm}$ diesel engine. They reported a significant reduction in all the emissions citing ample availability of oxygen as a cause. Dogan (2014) investigated the effect of adding butanol to diesel engine by $10 \%$ and $20 \%$ by volume. He found $4.4 \%, 5.4 \%$ and $2.9 \%$ reduction in $\mathrm{NO}_{x}, \mathrm{CO}$ and $\mathrm{HC}$ emissions respectively. $\mathrm{Li}$ et al. (2015) employed pentanol as an additive to diesel and found significant reduction in $\mathrm{NO}_{\mathrm{x}}$ and CO emissions at all loads. Gonca et al. (2016) examined the emission pattern of pentanol to diesel by means of pilot injection technique. They found a considerable reduction in $\mathrm{NO}_{\mathrm{x}}$ and smoke emissions. Atmanli et al. (2014) investigated the effect of appending butanol with vegetable oil. They found $2.8 \%$ reduction in $\mathrm{HC}$ emissions and $1.7 \%$ reduction in $\mathrm{CO}$ emissions by appending $20 \%$ of butanol to biodiesel.

Based on the review of previous studies, it can be concluded that no study has been conducted on blending pentanol at various proportions to neat palm oil biodiesel to view its effects on emission pattern. In this study, pentanol is chosen as an oxygenated additive and is blended with palm oil biodiesel at $10 \%$ and $20 \%$ by volume. Pentanol has a better potential to blend with diesel and biodiesel. Compared to other alcohols, it has five straight chain carbons with higher energy density, cetane number and better stability when blended. It also requires lesser energy during production (Rajesh et al., 2015). In this study, the test fuels used are namely; neat palm oil biodiesel (POBD100), pentanol appended with palm oil biodiesel by $10 \%$ volume (POBD90P10), pentanol blended with palm oil biodiesel by $20 \%$ volume (POBD80P20) and diesel. They fueled steady state diesel engines. The emission characteristics for all the test fuels were investigated and compared to view the effects of pentanol as an oxygenated additive.

\section{MATERIALS, METHODS AND REAGENTS}

\section{Palm Oil}

Palm oil is a vegetable oil derived from the mesocarp of the fruit of the oil palms, primarily the African oil palm, Elaeis guineensis and to a lesser extent from the American oil palm Elaeis oleifera and the maripa palm Attalea maripa. Palm oil is naturally reddish in colour because of its high beta-carotene content (Harmiwati and Rahmad, 2015). It is not to be confused with palm kernel oil derived from the kernel of the same fruit, or coconut oil derived from the kernel of the coconut palm (Lam et al., 2011). The fatty acid composition of neat palm oil biodiesel is listed in Table 1.

TABLE 1. FATTY ACID COMPOSITIONS OF PALM OIL BIODIESEL

\begin{tabular}{lc}
\hline Fatty acids & POBD100 $(\%$ mass $)$ \\
\hline Palmitic C16:0 & 35.9 \\
Stearic & 6.1 \\
Oleic & 46.1 \\
Linoleic C18:2 & 11.9 \\
Linoleic C18:3 & - \\
\hline
\end{tabular}

\section{Pentanol}

Pentanol $\left(\mathrm{C}_{5} \mathrm{H}_{11} \mathrm{OH}.\right)$ offers potential advantages when blended with diesel and biodiesel. It has five straight chain carbons with higher energy density, cetane number and better stability while blending compared to other alcohols. It also requires lesser energy during production (Rajesh et al., 2016). It is produced during fractional distillation of fossil fuels (Atmanli et al., 2016). Analytical grade pentanol is procured from local chemical suppliers (ThermoFisher chemicals). The physical and chemical properties of pentanol are listed in Table 2.

TABLE 2. PROPERTIES OF PENTANOL

\begin{tabular}{lc}
\hline Properties & Pentanol \\
\hline Molecular formula & $\mathrm{C}_{5} \mathrm{H}_{11}-\mathrm{OH}$ \\
Viscosity at $40^{\circ} \mathrm{C}\left(\mathrm{mm} \mathrm{s}^{-2}\right)$ & 2.88 \\
Flash point $\left({ }^{\circ} \mathrm{C}\right)$ & 49 \\
Latent heat of evaporation $\left(\mathrm{kJ} \mathrm{kg}^{-1}\right)$ & 308 \\
$\mathrm{C}(\% \mathrm{wt})$ & 68.18 \\
$\mathrm{H}(\% \mathrm{wt})$ & 13.64 \\
$\mathrm{O}(\% \mathrm{wt})$ & 18.18 \\
\hline
\end{tabular}

\section{Conversion of Palm Oil to Palm Oil Biodiesel}

The base catalysed transesterification process is carried out to convert the neat palm oil into palm oil biodiesel. A molar ratio of 6:1 (methanol to 
palm oil) and potassium hydroxide of $0.3 \%$ (wt/ $\mathrm{wt}$ ) is employed in the transesterification process. A sample containing $500 \mathrm{ml}$ of palm oil is heated at atmospheric condition till the oil attains $60^{\circ} \mathrm{C}$. A measured quantity of solution containing catalysts dispersed in methanol is then added and stirred at a constant stirring speed of $340 \mathrm{rpm}$ for $45 \mathrm{~min}$ and kept untouched to allow the formation of two layers (palm oil biodiesel and glycerol). Palm oil biodiesel is then removed by a gravity separation technique.

\section{Testing Facilities}

A constant speed (1300 rpm), single-cylinder, four-stroke, air-cooled diesel engine is employed in this study. The technical specifications of the engine employed in this study are listed in Table 3. Figure 1 shows the layout of the experimental set-up. Gas analyser (QROTECH type 402) is employed to compute the pollutants in the exhaust gas. Smoke concentration is computed by employing AVL 437 Smoke meter. The technical specifications of the gas analyser and smoke meter are listed in Table 4. Errors involved in the measurement of all the emissions are calculated by the procedure recommended by Moffat (1985). Table 5 shows the properties of diesel, palm oil biodiesel and pentanol blends.

\section{TABLE 3. TECHNICAL SPECIFICATION OF EXPERIMENTAL SET-UP}

\begin{tabular}{ll} 
Make & Kirloskar \\
Stroke & 4 \\
Cylinder & Single \\
Rated power & $4.2 \mathrm{~kW}$ \\
Rated speed & $1300 \mathrm{rpm}$ \\
Bore diameter (D) & $87.5 \mathrm{~mm}$ \\
Stroke (L) & $110 \mathrm{~mm}$ \\
Compression ratio & $17.5: 1$ \\
Injection timing & $17 \mathrm{bTDC}^{-1}$ \\
Injection pressure & $200 \mathrm{bar}$ \\
Fuel pump plunger diameter & $8 \mathrm{~mm}$ \\
Number of injector nozzle & 4 \\
Diameter of injector nozzle & $0.32 \mathrm{~mm}$ \\
Cooling & Air cooled \\
Position & Vertical \\
Type & Eddy current dynamometer \\
Make & Benz systems \\
Dynamometer constant & 2000 \\
Supply voltage & $240 \pm 10 \%$ AC, $50 \mathrm{~Hz}, 1 \phi$ \\
Maximum excitation current & 6 to 8 Amp \\
\hline
\end{tabular}

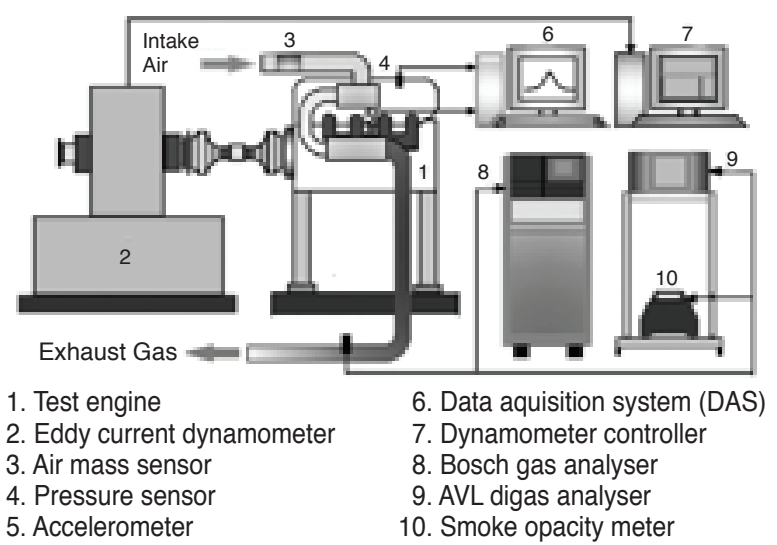

Figure 1. Layout of engine set-up.

TABLE 4. TECHNICAL SPECIFICATIONS OF GAS ANALYSER AND SMOKE METER

\begin{tabular}{|c|c|c|}
\hline \multirow{2}{*}{$\frac{\text { Model of gas analyser }}{\text { Pollutant }}$} & \multicolumn{2}{|c|}{ QROTECH type 402} \\
\hline & Range & Accuracy \\
\hline $\mathrm{CO}$ & $0 \%-9.99 \%$ & $0.01 \%$ \\
\hline $\mathrm{HC}$ & 0-1 $500 \mathrm{ppm}$ & $1 \%$ \\
\hline $\begin{array}{l}\mathrm{NO}_{x} \\
\text { Smoke meter }\end{array}$ & $0-5000 \mathrm{ppm}$ & $0.01 \%$ \\
\hline (AVL 437 smoke meter) & $0 \%-100 \%$ & $\pm 1 \%$ \\
\hline
\end{tabular}

\section{RESULTS AND DISCUSSION}

\section{Carbon Monoxide Emission (CO)}

Variation in brake specific carbon monoxide emissions with load for POBD100, POBD90P10, POBD80P20 and diesel is shown in Figure 2. CO emissions from palm oil biodiesel are less than diesel at all loads. This is because of the abundant availability of oxygen in palm oil biodiesel and pentanol blends (Li et al., 2015). CO emission reduces significantly with increase in pentanol percentage. By appending $10 \%$ and $20 \%$ of pentanol (volume basis) to neat palm oil biodiesel, $8.1 \%$ and 9.3\% of CO emissions is reduced. Pentanol release additional oxygen during combustion and enhance the rate of combustion Yuvarajan et al. (2017). Further, appending pentanol reduces the viscosity of neat palm oil biodiesel. The POBD100 with lesser viscosity assists improved evaporation of fuel with air in the cylinder and results in lower $\mathrm{CO}$ emissions. This result is in line with the experimental study

TABLE 5. PROPERTIES OF PALM OIL BIODIESEL AND ALCOHOL BLENDS

\begin{tabular}{lccccc}
\hline PROPERTIES & POBD100 & POBD90P10 & POBD80P20 & Diesel & Method \\
\hline Water content $(\%)$ & 0.12 & 0.11 & 0.11 & Nil & ASTM D2709 \\
Density @ $15^{\circ} \mathrm{C}\left(\mathrm{g} \mathrm{m}^{-3}\right)$ & 0.855 & 0.841 & 0.836 & 0.8200 & ASTM D4052 \\
Kinematic viscosity @40 ${ }^{\circ} \mathrm{C}\left(\mathrm{mm}^{2} \mathrm{~s}^{-1}\right)$ & 4.50 & 4.17 & 3.96 & 2.5 & ASTM D445 \\
Calorific value $\left(\mathrm{kJ} \mathrm{kg}^{-1}\right)$ & 41312 & 40967 & 40512 & 42957 & ASTM D240 \\
Cetane index $(\mathrm{CI})$ & 60 & 61 & 62 & 47 & ASTM D976 \\
Flash point in $\left({ }^{\circ} \mathrm{C}\right)$ & 172 & 173 & 172 & 50 & ASTM D93 \\
\hline
\end{tabular}


conducted by Atmanli (2016a) and Yuvarajan and Masuswamy (2017). The CO emissions for POBD100, POBD90P10, POBD80P20 and Diesel are $3.518 \mathrm{~g} \mathrm{kWhr}^{-1}, 2.083 \mathrm{~g} \mathrm{kWhr}^{-1}, 1.801 \mathrm{~g} \mathrm{kWhr}^{-1}$ and $3.754 \mathrm{~g} \mathrm{kWhr}^{-1}$ respectively at $100 \%$ load conditions.

\section{Hydrocarbons Emission (HC)}

Variation in brake specific hydro carbon emissions with load for POBD100, POBD90P10, POBD80P20 and diesel is shown in Figure 3. HC emissions from palm oil biodiesel are less than diesel at all loads. This is because of the rich availability of oxygen during combustion and higher cetane number in palm oil biodiesel and pentanol blends when compared to diesel (Dogan, 2011). HC emission reduces with the increase in pentanol percentage. By appending $10 \%$ and $20 \%$ of pentanol (volume basis) to neat palm oil biodiesel, $2.4 \%$ and $3.8 \%$ of $\mathrm{HC}$ emissions are reduced. This is due to the combined effect of higher oxygen content and reduced viscosity of POBD100. Lower viscosity of POBD90P10 and POBD80P20 improves the atomisation of fuel and enhances the combustion rate (Atmanli et al., 2014). Further, the rapid vaporisation of pentanol during combustion reduces the ignition delay and increases the rate of mixing between fuel and air in the cylinder. This in turn increases the burning rate of fuel and lowers unburned HC emissions (Rajesh et al., 2015). This result is in line with the experimental work done by Atmanli (2016b) and Yuvarajan and Manuswamy (2017). HC emissions for POBD100, POBD90P10, POBD80P20 and diesel are $0.36 \mathrm{~g} \mathrm{kWhr}^{-1}, 0.29 \mathrm{~g}$ $\mathrm{kWhr}^{-1}, 0.28 \mathrm{~g} \mathrm{kWhr}^{-1}$ and $0.39 \mathrm{~g} \mathrm{kWhr}^{-1}$ respectively at $100 \%$ load conditions.

\section{Oxides of Nitrogen Emission $\left(\mathrm{NO}_{\mathrm{x}}\right)$}

Variation in brake specific $\mathrm{NO}_{\mathrm{x}}$ emissions with load for POBD100, POBD90P10, POBD80P20 and diesel is shown in Figure 4. It is observed that the $\mathrm{NO}_{\mathrm{x}}$ emission from palm oil biodiesel is higher than diesel at all loads. Higher inbuilt oxygen in the palm oil biodiesel and pentanol blends promotes combustion and raises the temperature during combustion (Koc et al., 2013; Choi et al., 2015). $\mathrm{NO}_{\mathrm{x}}$ emission reduces with increase in pentanol

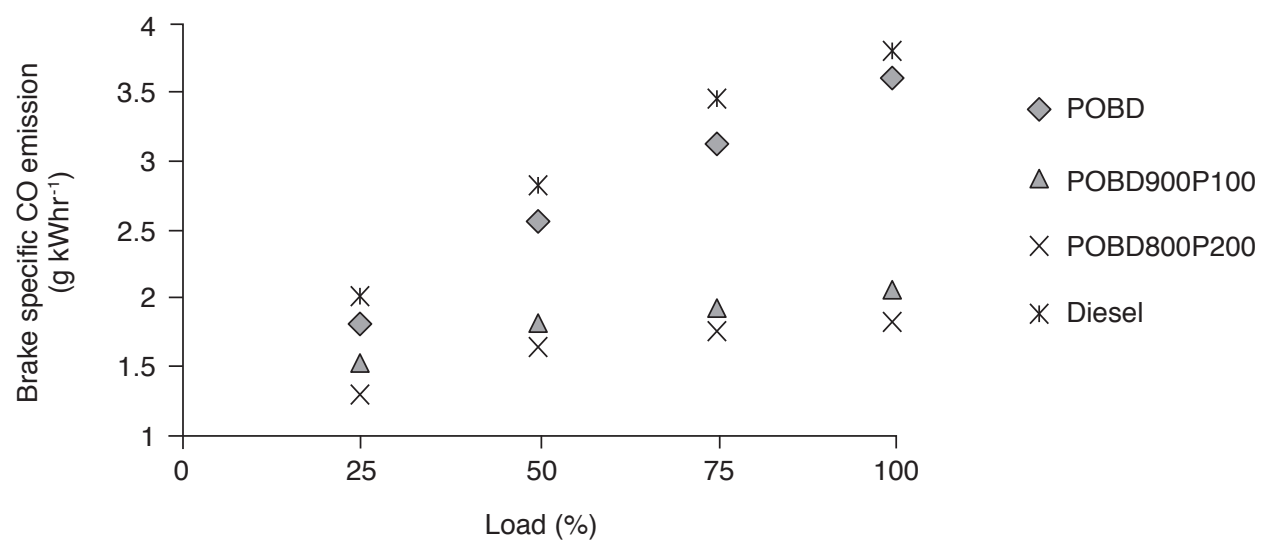

Figure 2. Variation of carbon monoxide (CO) with load.

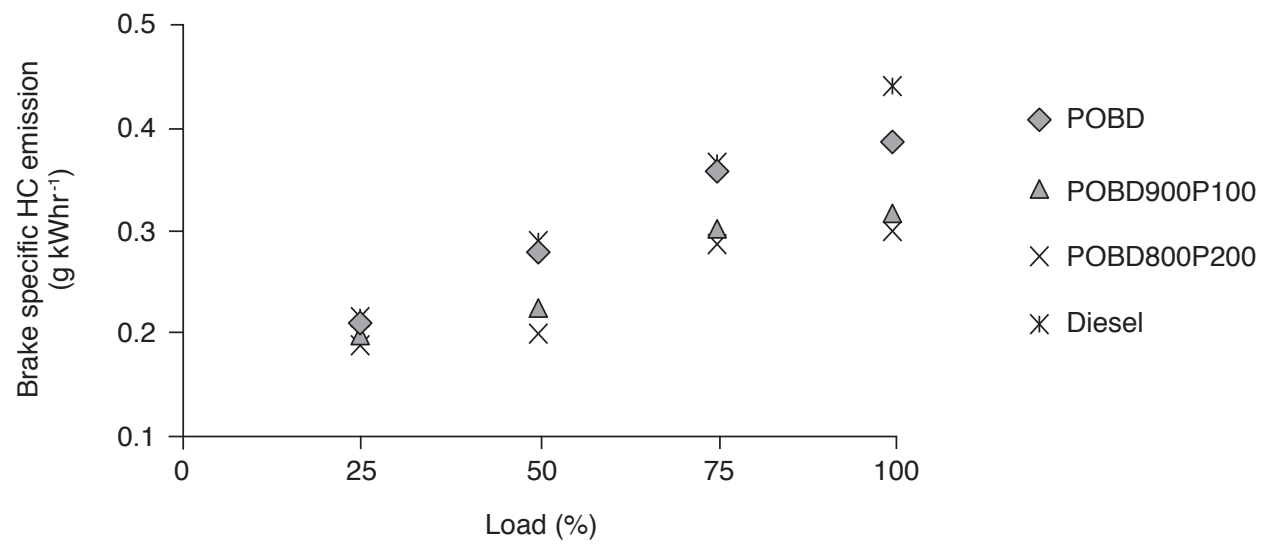

Figure 3. Variation of hydrocarbon emission (HC) with load. 
percentage. By appending $10 \%$ and $20 \%$ of pentanol (volume basis) to neat palm oil biodiesel, $4.2 \%$ and $6.6 \%$ of $\mathrm{NO}_{\mathrm{x}}$ emissions are reduced.

Appending pentanol to palm oil biodiesel reduces its calorific value which in turn reduces the cylinder combustion temperature (Rajesh and Saravanan, 2015). In addition, appending pentanol to palm oil biodiesel reduces its kinematic viscosity. Fuel with lower kinematic viscosity (POBD90P10 and POBD80P20) enhances the contact between air and fuel in the cylinder during combustion and aids the improved combustion and lower $\mathrm{NO}_{\mathrm{x}}$ emissions. This result is in line with similar earlier work carried out by Atmanli (2016b) and Yuvarajan and Manuswamy (2017). The $\mathrm{NO}_{x}$ emissions for POBD100, POBD90P10, POBD80P20 and diesel are $11.9 \mathrm{~g} \mathrm{kWhr}^{-1}, 11.6 \mathrm{~g} \mathrm{kWhr}^{-1}, 11.4 \mathrm{~g} \mathrm{kWhr}^{-1}$ and $10.9 \mathrm{~g}$ $\mathrm{kWhr}^{-1}$ respectively at $100 \%$ load conditions.

\section{Smoke Concentration}

Variation in smoke concentration with load for POBD100, POBD90P10, POBD80P20 and diesel is shown in Figure 5. Smoke concentration for palm oil biodiesel and pentanol blends is lesser than diesel. This is as a result of inherent oxygen content present in palm oil biodiesel (Gonca et al., 2016; Venkata Ramanan and Yuvarajan, 2015). Smoke concentration reduces with increase in pentanol percentage. By appending $10 \%$ and $20 \%$ of pentanol on volume basis to neat palm oil biodiesel, $1.9 \%$ and $2.7 \%$ of smoke concentration is reduced. Higher oxygen content in pentanol and palm oil biodiesel improves the rate of combustion. In addition, oxygen atoms in palm oil biodiesel and pentanol get bonded to hydroxyl group and reduce smoke concentration (Rajesh and Savaranan, 2015). Smoke emissions for POBD100, POBD90P10, POBD80P20 and diesel are $1.1,0.9,0.7$ and $1.3 \mathrm{BSU}$ respectively at $100 \%$ load conditions. The result is in line with the similar work by Choi and Jiang (2015) and Yuvarajan and Manuswamy (2017).

\section{CONCLUSION}

An experimental investigation is performed to evaluate the emissions characteristics of palm oil biodiesel and pentanol blends in $1300 \mathrm{rpm}$ constant speed diesel engine. Emissions such as $\mathrm{CO}, \mathrm{HC}$,

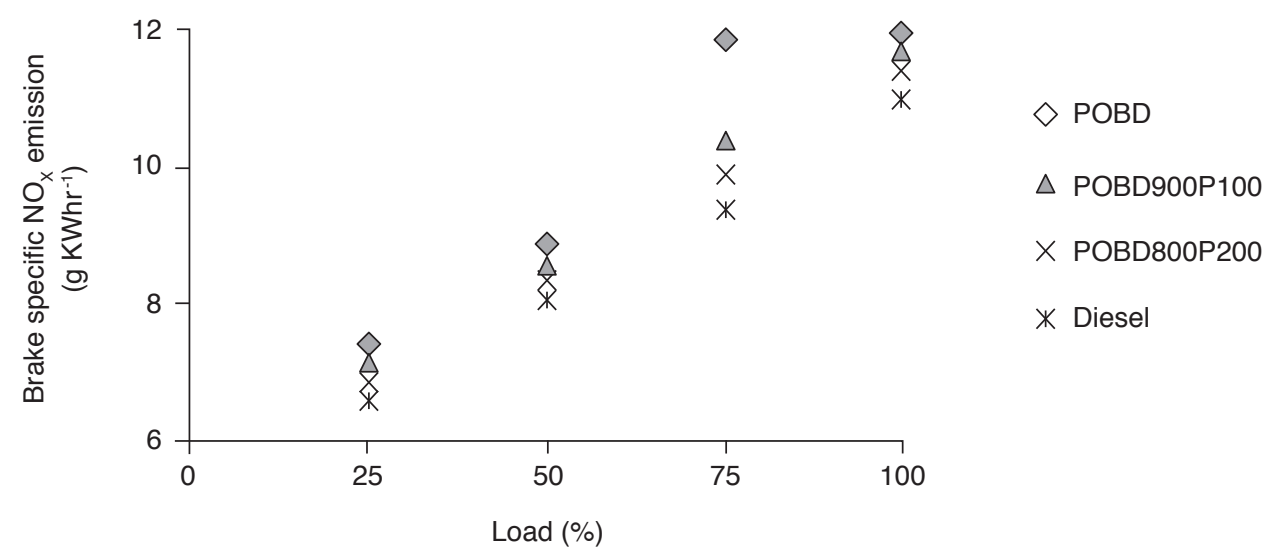

Figure 4. Variation of nitrogen emissions $\left(\mathrm{NO}_{\mathrm{X}}\right)$ with load.

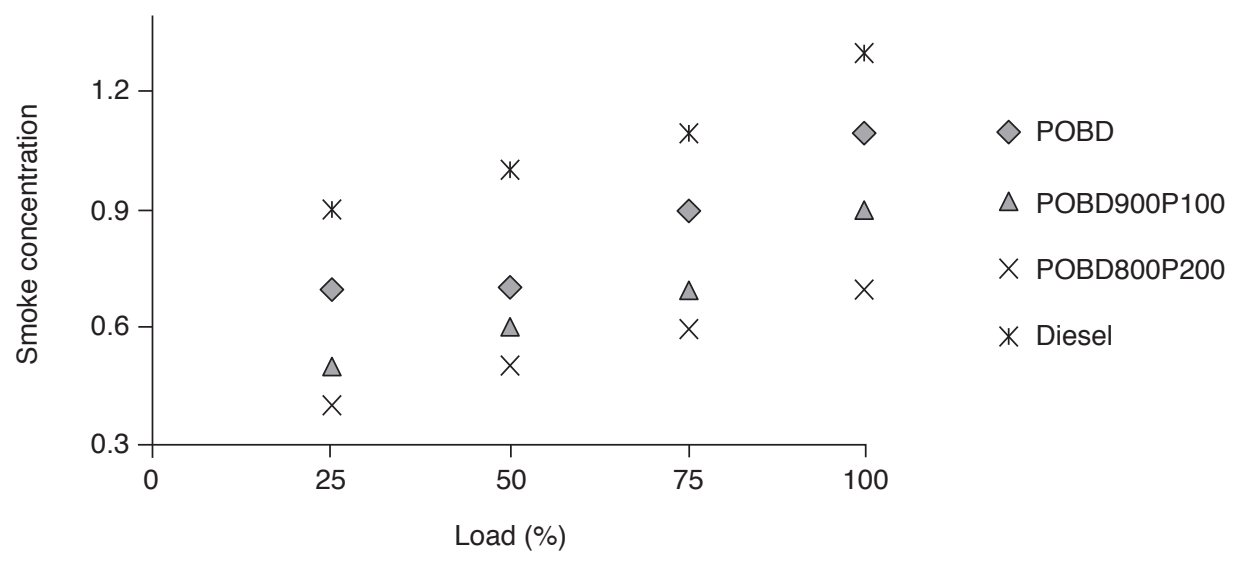

Figure 5.Variation of smoke with load. 
$\mathrm{NO}_{x^{\prime}}$ and smoke concentration are measured for each test fuel. The following are the major findings from this study:

- palm oil biodiesel can be used as a fuel without any major modification in diesel engine;

- no surfactants were employed for blending of palm oil biodiesel with higher alcohols;

- overall CO emissions for palm oil biodiesel are reduced by $8.1 \%$ and $9.3 \%$ by blending it with 100 and $200 \mathrm{ml}$ of pentanol;

- HC emissions palm oil biodiesel are reduced by $2.4 \%$ and $3.8 \%$ by blending it with 100 and $200 \mathrm{ml}$ of pentanol;

- appending 100 and $200 \mathrm{ml}$ of pentanol to palm oil biodiesel reduced overall $\mathrm{NO}_{\mathrm{x}}$ emissions by $4.2 \%$ and $6.6 \%$ at all loads; and

- blending 100 and $200 \mathrm{ml}$ of pentanol to palm oil biodiesel reduced overall smoke concentration by $1.9 \%$ and $2.7 \%$ at all loads.

\section{REFERENCES}

AMIRNORDIN, S H; IHSANULHADI, N; ALIMIN, A J and KHALID, A (2013). Effects of palm oil biodiesel blends on the emissions of oil burner. Appl. Mech Mat., 315: 956-959.

ATMANLI, A (2016). Comparative analyses of diesel-waste oil biodiesel and propanol, n-butanol or 1-pentanol blends in a diesel engine. Fuel, 176: 209-215.

ATMANLI, A (2016). Effects of a cetane improver on fuel properties and engine characteristics of a diesel engine fueled with the blends of diesel, hazelnut oil and higher carbon alcohol. Fuel, 172: 209-217.

ATMANLI, A; ILERI, E and YUKSEL, B (2014). Experimental investigation of engine performance and exhaust emissions of a diesel engine fueled with diesel-n-butanol-vegetable oil blends. Energ Convers Manage., 81: 312-321.

CAMPOS-FERNANDEZ, J; ARNAL, J M; GOMEZ, J; LACALLE, N and DORADO, M P (2013). Performance tests of a diesel engine fueled with pentanol/diesel fuel blends. Fuel, 107: 866-872.

CHOI, B and JIANG, X (2015). Individual hydrocarbons and particulate matter emission from a turbocharged CRDI diesel engine fueled with n-butanol/diesel blends. Fuel, 154: 188-195.

RAKOPOULOS, D C; RAKOPOULOS, C D; GIAKOUMIS, E G; DIMARATOS, A $\mathrm{M}$ and KYRITSIS, D C (2010). Effects of butanol-diesel fuel blends on the performance and emissions of a high-speed DI diesel engine. Energ Convers Manage., 51(10): 1989-1997.

DOGAN, O (2011). The influence of n-butanol/ diesel fuel blends utilization on a small diesel engine performance and emissions. Fuel, 90(7): 2467-2472.

GIAKOUMIS, E G; RAKOPOULOS, C D; DIMARATOS, A M and RAKOPOULOS, D C (2012). Combustion noise radiation during the acceleration of a turbocharged diesel engine operating with biodiesel or n-butanol diesel fuel blends. P I Mech Eng D-J Aut., 226(7): 971-986.

GONCA, G and DOBRUCALI, E (2016). The effects of engine design and operating parameters on the performance of a diesel engine fueled with dieselbiodiesel blends. J. Renew Sust Energ Vol., 8(2): 025702 .

HARMIWATI and RAHMAD, D (2015). Transesterification of crude palm oil liquid waste to biodiesel. Ad Mat Res., 1115: 357-360.

KARABEKTAS, $\mathrm{M}$ and HOSOZ, M (2009). Performance and emission characteristics of a diesel engine using isobutanol-diesel fuel blends. Renew Energ., 34 (6): 1554-1559.

KOC, A B and ABDULLAH, M (2013). Performance and $\mathrm{NO}_{\mathrm{x}}$ emissions of a diesel engine fueled with biodiesel-diesel-water nanoemulsions. Fuel Processing Technol., 109: 70-77.

LAM, M K and LEE, K T (2011). Production of biodiesel using palm oil. Biofuels. p. 353-374.

LI, L; WANG, J; WANG, Z and XIAO, J (2015). Combustion and emission characteristics of diesel engine fueled with diesel/biodiesel/pentanol fuel blends. Fuel, 156: 211-218.

MOFFAT, R J (1985). Using uncertainty analysis in the planning of an experiment. J. Fluids Eng., 107(2): 173.

MURCAK, A; HASIMOGLU, C; CEVIK, I; KARABEKTAS, M and ERGEN, G (2013). Effects of ethanol-diesel blends to performance of a DI diesel engine for different injection timings. Fuel, 109: 582587.

RAJESH KUMAR, B and SARAVANAN, S (2015). Effect of exhaust gas recirculation (EGR) on performance and emissions of a constant speed DI diesel engine fueled with pentanol/diesel blends. Fuel, 160: 217-226.

RAJESH KUMAR, B; MUTHUKKUMAR, T; KRISHNAMOORTHY, $\mathrm{V}$ and SARAVANAN, S 
(2016). A comparative evaluation and optimization of performance and emission characteristics of a DI diesel engine fueled with n-propanol/diesel, n-butanol/diesel and n-pentanol/diesel blends using response surface methodology. RSC Adv., 6(66): 61869-61890.

RAKOPOULOS, D C; RAKOPOULOS, C D; GIAKOUMIS, E G; PAPAGIANNAKIS, R G and KYRITSIS, D C (2014). Influence of properties of various common bio-fuels on the combustion and emission characteristics of high-speed DI (direct injection) diesel engine: vegetable oil, bio-diesel, ethanol, n-butanol, diethyl ether. Energ., 73: 354-366.

JAAT, M; KHALID, A; MANSHOOR, B; RAMSY, H and MUSTAFFA, N (2014). An experimental study on the performance and emissions of diesel engine fuelled with biodiesel derived from palm oil. Appl Mech Mat., 699: 654-659.
VENKATA RAMANAN, $\mathrm{M}$ and YUVARAJAN, D (2016). Emission analysis on the influence of magnetite nanofluid on methyl ester in diesel engine. Atmos Pollut Res., 7(3): 477-481.

WANG, Z; LIU, H; ZHANG, J; WANG, J and SHUAI, S (2015). Performance, combustion and emission characteristics of a diesel engine fueled with polyoxymethylene dimethyl ethers (PODE34)/ diesel blends. Energy Procedia., 75: 2337-2344.

YUVARAJAN, D (2017). Performance and emissions analysis on diesel engine fuelled with cashew nut shell biodiesel and pentanol blends. Korean J. Chem.. Eng., 34(4): 363-364.

YUVARAJAN, D and MUNUSWAMY, D B (2017). Emissions analysis on diesel engine fuelled with cashew nut shell biodiesel and pentanol blends. Environ. Sci. Pollut. Res. 